\title{
The relationship between education and self-sustainability in a stressed economy
}

\author{
Kemi Olalekan Oduntan \\ Department of Economics \\ School of Arts and Social Sciences \\ Tai Solarin College of Education \\ Omu-Ijebu, Ogun State, Nigeria \\ E-mail: kemioduntan1@gmail.com \\ Cell: +2348023688339
}

\begin{abstract}
Education is an important key in achieving sustainable national development. For a state or society to achieve sustainable development, the quality of its education should be an issue of great concern. This paper examined the relationship between education and self-sustainability in Nigeria. It also provided insights into various challenges confronting education in Nigeria such as gender inequity in education, dearth of teachers, inadequate infrastructures, overcrowded classrooms and inadequate remunerations. Data from Central Bank of Nigeria Statistical Bulletin where recurrent expenditures on education and social and community services as well as Gross Domestic Products for 1985 to 2017 were used. The study also suggested ways on how to solve the identified challenges confronting education in Nigeria. The study recommends the creation of conducive atmosphere for learning, increasing financial allocation for educational development, ensure gender quality in education, and setting up a committee that will manage and supervise education policies that will involve sustainability.
\end{abstract}

Keywords: Change, Education, Gender inequality, Infrastructure, Self-Sustainability

\section{Introduction}

Nigeria, a giant nation in West African subregion is blessed with abundant human and mineral resources across her six geo-political zones. However, despite this, it is classified among poor African nations characterized by abject poverty because of the low level of economic development. This, without doubt is connected to the low level of educational achievement and high rate of illiteracy in the country. Education is a multidimensional concept which can be described as the inculcation of adequate knowledge, skills and desirable attitudes cherished by society and considered for harmonious living. Education is a life-long process by which an individual is groomed in necessary skills and morals that would assist him in solving life challenges. Isa (2016) reflected that education is a mechanism for social and economic development of the people which contributes to economic growth through eradication of poverty and wealth creation.

The level of education of any given society is linked to the quality of skilled manpower available to drive production and service delivery processes as veritable instruments for socio-political and economic development in this ever changing world. This assertion therefore underscores the significant role of education in human capital development, poverty alleviation, eradication of diseases and wealth creation in any given nation. Supporting this thought pattern, Ezekiel and Musa (2013) declared that education is a tool for change and development in terms of politics, economics and social life. However, the dilemma in Nigeria educational system is inimical to sustainable economic development. In view of the above expositions, this paper discusses educational dilemma as an hindrance to sustainable economic development in Nigeria.

The real problem facing humanity today in terms of achieving sustainable development is how to motivate people to change underlying attitudes, behaviours and activities that are unproductive in this case unsustainability. Human beings are very resentful to change. In other words, people should be encouraged to channel their energy 
Kemi Olalekan Oduntan: The relationship between education and self-sustainability in a stressed economy

towards contributing more to help alleviate poverty by acquiring relevant education and skills in order to promote developmental efforts that do not pollute good ideas and wasting scarce resources to destroy lives and edifices built over the years (Peter O.M and Juliana D. 2010). Here is where the idea of education for sustainable development has a special role in vindicating how various processes in education, which lie at the heart of promoting change in human behaviour, can be used on a global level to help turn things around (Baba, 2005). Hence, this research work "Education and self-sustainability in a stressed Economy", and an issue that has global dimension, is appropriate in times like these. While a range of approaches is needed to cope with these problems, it is argued that education has a special role and responsibility in contributing to the challenges of sustainability.

\section{Literature review}

Sustainability in education is a complex concept. It is also continually evolving, which makes it difficult to define. One of the original descriptions of sustainability is credited to the Brundtland Commission; "sustainability is a development that meets the needs of the present without compromising the ability of future generations to meet their own needs" (World Commission on Environment and Development, 1987, p 43). Sustainability is generally thought to have three components; environment, society, and economy. The well-being of these three areas is entangled, not separate. For example, a healthy, prosperous society relies on a healthy environment to provide quality education, food and resources, safe drinking water, and clean air for its citizens. The sustainability paradigm rejects the contention that casualties in the environmental and social realms are inevitable and acceptable consequences of economic development. Thus, sustainability is treated as a paradigm for thinking about a future in which environmental, societal, and economic considerations are balanced in the pursuit of development and improved quality of life . An important distinction is the difference between education about sustainable development and education for sustainable development. The first is an awareness lesson or theoretical discussion. The second is the use of education as a tool to achieve sustainability.

The term education has been defined and conceptualized in a number of ways. Okoh in Okorosaye-Orobite (2005) sees education as a process, a product, and a discipline. As a process, it "is the activity of preserving, developing, and transmitting the culture of a people from one generation to another". As a product "it refers to change, whether overt or covert, implicit or explicit, which education is expected to bring about". Also Akinpelu in Okorosaye-Oribite (2005:19) stresses that the product of education is the educated man, who in the African context is one "who shows evidence of a well-integrated personality ... he is economically efficient, socially and publically competent, morally acceptable and intellectually and culturally sophisticated". Ukeje (1986) summed it up when he opined that,

Education is power, it is a
process of acquiring knowledge
and ideas that shape and
condition man's attitude, actions
and achievements; it is a process
of developing the child's moral,
physical, emotional and
intellectual power for his
contribution in social reform; it is
the process of mastering the laws
of nature and for utilizing them
effectively for the welfare of the
individual and for social
reconstruction; it is the art of the
utilization of knowledge for
complete living.

Education is the largest part of UNESCO's operations, in terms of allocation, financial and staffing resources. UNESCO seeks to help its member states strengthen and upgrade education and schooling, with 
Kemi Olalekan Oduntan: The relationship between education and self-sustainability in a stressed economy

particular reference to promoting best innovative practices. UNESCO Medium Term strategy 2008-2013 paragraph 3 (in Maclean, 2008) states:

Development and economic
prosperity depend on the ability of
countries to educate all members
of their societies and offer them
lifelong learning. An innovate
society prepares its people not
only to embrace and adapt to
change but also to manage and
influence it. Education enriches
cultures, creates mutual
understanding that underpins
peaceful societies. UNESCO is
guided by upholding education as
a human right and as an essential
element for the full development
of human potentials.

Maclean (2008) notes that, although there are many keys to development, such as improved infrastructure such as dams, roads, telecommunication facilities, ports and the like, education is regarded as being the master key to economic and social development. High quality and relevant education and schooling have been shown to open the doors to: poverty alleviation, sustainable development, equity, justice, and mainstreaming of the marginalized as well as vulnerable groups in society.

Education constitutes the major instrument for sustainable human development and serves as a fulcrum around which every other activity revolves (Tahir, 2006:21). Nations which have recorded tremendous feats in the world heavily relied on the instrumentality of education. However, in Nigeria there seems to be a daily decline of educational standards. Former president Olusegun Obasanjo in his Presidential Speech on April, 24, 2000 in Dakar Senegal, attributed the educational falling standard to bad governance. In his speech; he stated that:

Nigerian educational system as it stands is a living proof of the damages that bad governance can do to our society and social structure.
- Human beings are the architects and engineers of progressive change and development and they constitute the most important resources we can have internally.

Tahir (2006), identified a number of daunting challenges which Nigerian education is confronted with. They are:

i. Gender equity in education;

ii. Dearth of teachers;

iii. Overcrowded classrooms;

iv. Inadequate infrastructures;

v. Funding of education.

According to Osalor (2013), the Nigerian state operates in a $21^{\text {st }}$ Century economy with a $19^{\text {th }}$ Century education system. A system whereby much emphasis is still placed on the conventional classroom environment with much reverence for certificate for graduates, who in most cases are trained to be job seekers, as evidenced in present high unemployment rates in the land (Osalor, 2013). Muoghalu (2013a) posits that Nigeria's education system, while improving, is not fit for the demands of competitive global markets, as the system does not provide Nigerians with the skills they need to get jobs. Okonjo-Iweala, et al (2010) highlights that the education most Nigerians receive is of dubious quality, and illiteracy remains high, even among those who attend school. Large numbers of children are regularly absent from school and must repeat years. In addition, facilities such as comfortable classrooms, good hostels, laboratories, standard libraries and sporting facilities, for recreation and physical development, are either in short supply, dilapidated or totally non-existent. Furthermore, many teachers lack the skills to do their jobs, while many still are frustrated due to poor working conditions or nonpayment of salaries which in some instances are in arrears for months. Only recently, the media was awash with the startling story of a school teacher in Benin City, who could not read a book, to the shock of many Nigerians (Muoghalu, 2013a). A locus classics on the state of education in Nigeria is provided by Muoghalu (2013b), cited in Muoghalu 
Kemi Olalekan Oduntan: The relationship between education and self-sustainability in a stressed economy

(2013a). The highlights of the issues raised in this contribution include:

i. The problem of access reflected in the high occurrence of out-of-school children currently estimated at about 10million. While a number of African countries made progress in school enrolments over the past decade, Nigeria regressed. The country's net primary school enrolment rate dropped to 58 percent in 2010 from 64 percent in 1999. The primary school completion rate in Nigeria was approximately 75 percent between 2003 and 2010, but in Ghana the rate improved markedly from 69.6 percent to 88 percent, in Tanzania it rose from 55 percent to 90 percent over the same period.

ii. The low rate of secondary school enrolment which reflects the trend in Africa. Only 28 percent of Africa's youths are enrolled in secondary school, and while a child entering the education systems of an OECD country has an 80 percent likelihood of going on to university or some other form of tertiary education, only 6 percent in sub-Saharan African have similar chances.

iii. The progressive erosion of the culture of education over the past three decades, reflecting a collapse of value systems.

iv. The prioritization of access over quality in the quest to meet the Millennium Development Goals which included a target of education for all by 2015.

v. Secondary school terminal examinations organised by the West African Examinations Council (WAEC) and the National Examinations Council (NECO) have witnessed mass failures for the past several years. Only 5.75 percent of the 803,360 private candidates that sat the West African Senior Secondary School Certificate Examination in 2010 received 5 Credits (Cs) and above with English Language included, and 10 percent did so with Mathematics included. Nigerian secondary school students have become progressively weaker in the science subjects that lay the foundation for a knowledge economy based on science, technology and innovation. In the 2006 West African School Certificate Examinations, only 23 percent of candidates made passing grades in science subjects, with the pass ratios in subsequent years dropping or hovering at 20 percent in 2007, 26 percent in 2009, 26 percent in 2010, and 23 percent in 2011.

vi. The tertiary education system is plagued by weak learning infrastructure and low-quality teachers - the two factors that affect learning outcomes. University education has existed in an advanced state of decay for over two decades. Even first generation Nigerian universities have seen their accreditations withdrawn or threatened as a result of poor educational infrastructure such as libraries, classroom facilities, and student housing. Several universities are producing graduates that lack the right skills needed to perform tasks required in their chosen fields, making it difficult for them to get employment. No single university in Nigeria was featured in the Times High Education 400 Universities in the World rankings for 2011-2012, yet there were representatives from South Africa and Egypt.

vii. In Africa, no Nigerian university is listed in the top 20 - yet there are universities in Ethiopia, Sudan, Ghana, Kenya and Uganda in this list. The lecturer-to-student ratios have worsened. The ratio of teaching staff to students is $1-122$ at the University of Abuja and 1-144 at the Lagos State University; but the same ratio is $1-4$ at Harvard University, 1-9 at the Massachusetts Institute of Technology 
Kemi Olalekan Oduntan: The relationship between education and self-sustainability in a stressed economy

(MIT), 1-3 at the University of Cambridge, and 1-10 at the National University of Singapore.

There is a dearth of qualified teachers at all levels of education. The report of a presidential panel on the needs of public institutions indicates a manpower crisis in Nigerian universities. Only 43 percent of academic staff in Nigerian public universities earned doctorate degrees. The remaining 57 percent do not have such minimum qualifications for university teaching. Just seven universities had up to 60 percent of their teaching staff with PhDs and Kano State University of Science and Technology, established in 2002, had one professor and 25 lecturers with doctorate degrees, while 74 percent of teaching staff at the Plateau State University in Bokkos are visiting faculty (Muoghalu, 2013a).

A proper and purposeful conceptualization of sustainable development would organically relate with the primary concept of development. However, let it be acknowledged instantly that development in human society is a many-sided process (Rodney, 2009). Okwueze (2011) highlights that development (a prelude to sustainable development) is geared towards the improvement of the standard of living of the people. Development means growth integrated with economic, scientific, political and home based technological expansion (Enamiroro, 2007). According to Rodney (2009) at the level of the individual, development implies increased skill and capacity, greater freedom, creativity, selfdiscipline, responsibility and material wellbeing. Some of these are virtually moral categories and are difficult to evaluate depending as they do on the age, one's class origins, and -personal code of what is right and what is wrong. However, what is indisputable is that the achievement of any of those aspects of personal development is very much tied-in with the state of the society as a whole (Rodney, 2009). It is the state of the society that determines sustainable development.
Estes (1993), cited in Nzekwe and Okeke (2014) highlights that credit for originating the "sustainable development" concept is generally given to the 1987 report of World Commission on Environment and Development (WCED, 1987). Popularly referred to as the Brundtland Commission; the Commission's report, Our Common Future: From One Earth to One World, called for emboldened and dramatically new conceptions of developing that advanced the material wants of the present generation without depriving future generations of the resources required to satisfy their needs. Thus, the Commission conceptualized "sustainable development" rather simply as paths of human progress which meet the needs and aspirations of the present generation, without compromising the ability of future generations to meet their needs (Estes, 1993). Today, the sustainable development "movement" is multidisciplinary and cross-sectoral. The movement brings together specialists from the physical and environmental sciences along with experts in development economics, political science, appropriate technology, human and women's rights, and others (Estes, 1993). Despite the apparent simplicity of the Brundtland Commission's definition of sustainable development, the concept itself is rather complex (Estes, 1993).

This study has not overburdened its concerns with the complexities of the concept of sustainable development. In this study therefore, sustainable development is underscored as human progress which meet the needs and aspirations of the present generation, without compromising the ability of future generations to meet their own needs (Nzekwe and Okeke, 2014). The purpose of the study was to examine the relationship between education and self-sustainability in Nigeria, as well as provide insights into various challenges confronting education in Nigeria.

\section{Hypotheses}

The study was guided by the following hypotheses: 
Kemi Olalekan Oduntan: The relationship between education and self-sustainability in a stressed economy

1. There is no significant relationship between recurrent expenditure on education and economic growth in Nigeria.

2. There is no significant relationship between social and community development expenditure and economic growth in Nigeria.

\section{Methods}

The data for this research work is secondary and the samples were drawn from online statistical bulletins and economic reviews of the Central Bank of Nigeria and data drawn for the period of 32 years (1985 - 2017).

\section{Model specification}

$$
G D P=\beta_{0}+\beta_{1} R E E+\beta_{2} S C E+\mu_{1}
$$

Where,

$\mathrm{Y}$ is dependent variable and $\mathrm{X}_{1}$ and $\mathrm{X}_{2}$ are independent variables.

GDP $=$ Gross Domestic Product (GDP)

REE $=$ Recurrent Expenditure on

Education (REE)

SCE = Social and Community Service

Expenditure (SCE)

$\beta_{0}=$ Representing Constant

$\beta_{1}=$ Coefficient of Net Education

$\beta_{2}=$ Coefficient of Social and

Community Services

$\mu=$ Error Term

\section{Estimation techniques}

The Ordinary Least Square method (OLS) of the linear regression model was adopted due to the following reasons:

Table 1a: Descriptive analysis of variables

$\begin{array}{llll} & \text { GDP } & \text { REE } & \text { SCE } \\ \text { Mean } & 28768.89 & 113.2767 & 251.4327 \\ \text { Median } & 9060.300 & 57.96000 & 84.79000 \\ \text { Maximum } & 113711.6 & 394.9000 & 904.9000 \\ \text { Minimum } & 1257.200 & 0.170000 & 0.650000 \\ \text { Std. Dev. } & 34510.93 & 137.2229 & 323.8816 \\ \text { Skewness } & 1.162146 & 1.015967 & 1.033994 \\ \text { Kurtosis } & 2.960635 & 2.481774 & 2.399584 \\ \text { Jarque-Bera } & 7.430343 & 6.046312 & 6.375974 \\ \text { Probability } & 0.024351 & 0.048647 & 0.041255 \\ \text { Sum } & 949373.5 & 3738.130 & 8297.280 \\ \text { Sum Sq. Dev. } & 3.81 \mathrm{E}+10 & 602563.8 & 3356777 . \\ \text { Observations } & 33 & 33 & 33\end{array}$

Tropical Journal of Education, Volume 2, Numbers 1/2, 2020
1. The mechanism of the OLS is simple to understand and interpret

2. The equation is specified in a linear form and fairly easy to compute compared to econometric method and

3. The parameters estimated by the OLS method have some desirable optical properties which are best linear, unbiased estimator.

\section{Apriori expectation}

$\beta_{1}$ and $\beta_{2}>0$

Therefore, all the variables are expected to have significant relationship with GDP because an increase in education expenditure and social/community service expenditure will directly or indirectly have effect on selfsustainability of Nigerians.

\section{Results and discussion}

Descriptive profiles of variables

From table 1 below, the skewness is an indicator of the asymmetry or deviation of the variables from a normal distribution with an expected value of zero. The Kurtosis defines the degree of flattening or peakedness of a distribution with an expected value of three. Jarque bera statistics determine the normality or otherwise of a distribution. GDP, REE and SCE have their skewness greater than zero (positively skewness), the kurtosis are approximately three (mesokurtic) and their Jarque bera statistics of $(7.430,6.046$ \& $6.375)$ respectively denote that their errors are normally distributed.

251.4327

84.79000

0.650000

23.8816

399584

6.375974

.041255

356777

33 
Kemi Olalekan Oduntan: The relationship between education and self-sustainability in a stressed economy

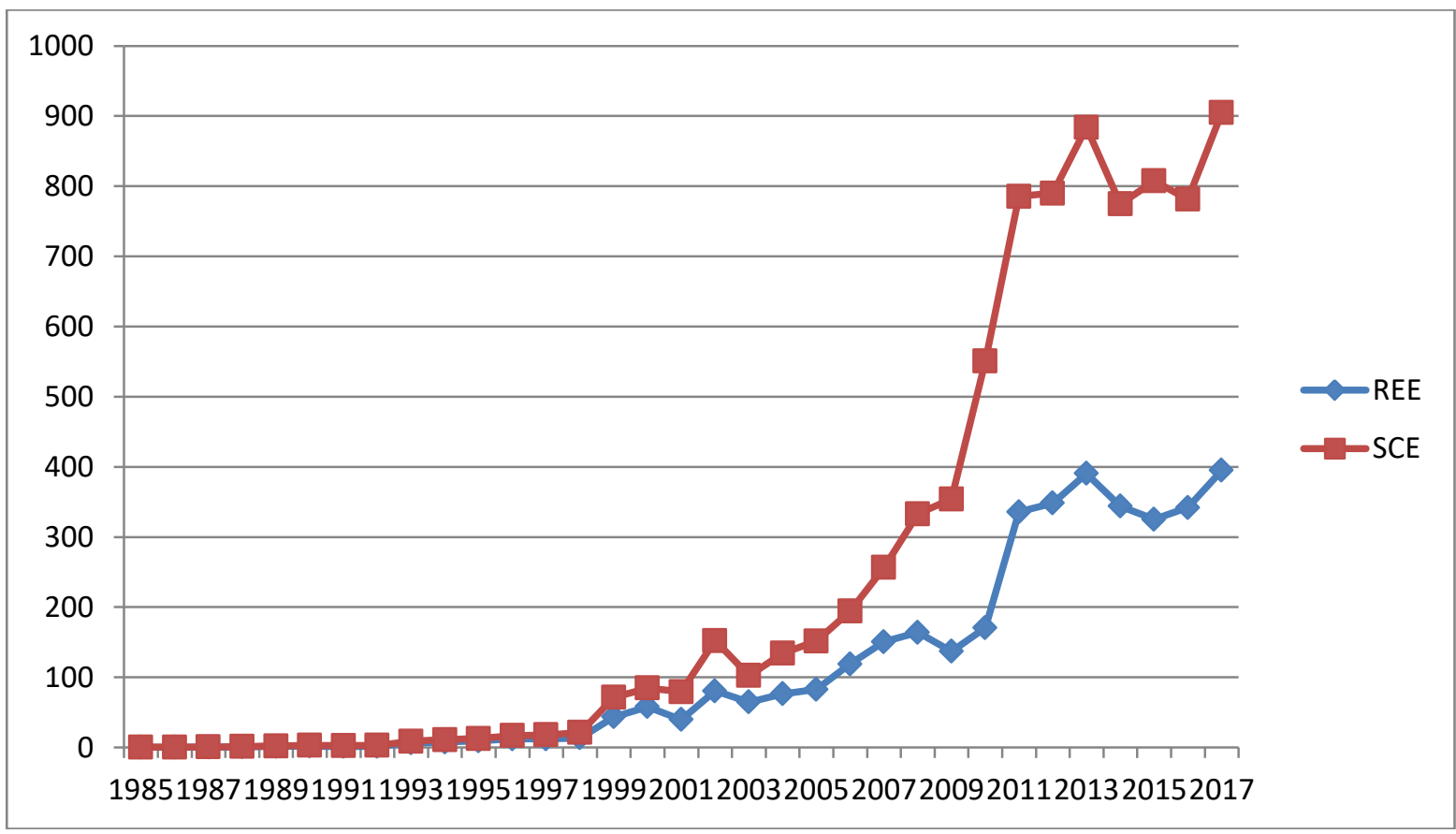

Figure 1a: Trend of recurrent expenditure on education and social \& community service expenditure REE \& SCE (N Billion)

Figure 1a displays the trend of the annual recurrent expenditure on education as well as on social and community service expenditure over the years under consideration. From 1985 to late 1990s, it is evident graphically that the level of increase in both variables is very low. This implies that within this period recurrent expenditure on education as well as on social and community service experienced a linear graphical trend. This period coincided with the adoption of Structural Adjustment Programme (SAP) aimed at revitalizing the economy through depreciation of the country's currency. Furthermore, the variables begin to experience aggregate increase from 1999 till date, though with several fluctuations which may be attributed to several macro and micro economic variables as well as political institutional changes.

Nigeria is characterized as a middle income, mixed economy and emerging market with expanding financial, service, communication and entertainment sector. The country is ranked $30^{\text {th }}$ in the world in terms of GDP and $1^{\text {st }}$ on its continent. Generally, persistent economic growth of any country is an indicator of how well such economy can be self-sustained, however, the increase in economic growth is the combination of several economic parameters, policies, frameworks and so on which in turn increase aggregate production. The trend analysis of GDP in (figure 1b) reveals that Nigeria economy has grown over the years. However, the graphical illustration shows that there was a slight reduction in the country's GDP in 1993 while this was managed over years before the economy was able to regain its competency in early 2000s. The reduction phenomenon could be attributed to corruption and mismanagement by some military head of state during the period. 
Kemi Olalekan Oduntan: The relationship between education and self-sustainability in a stressed economy

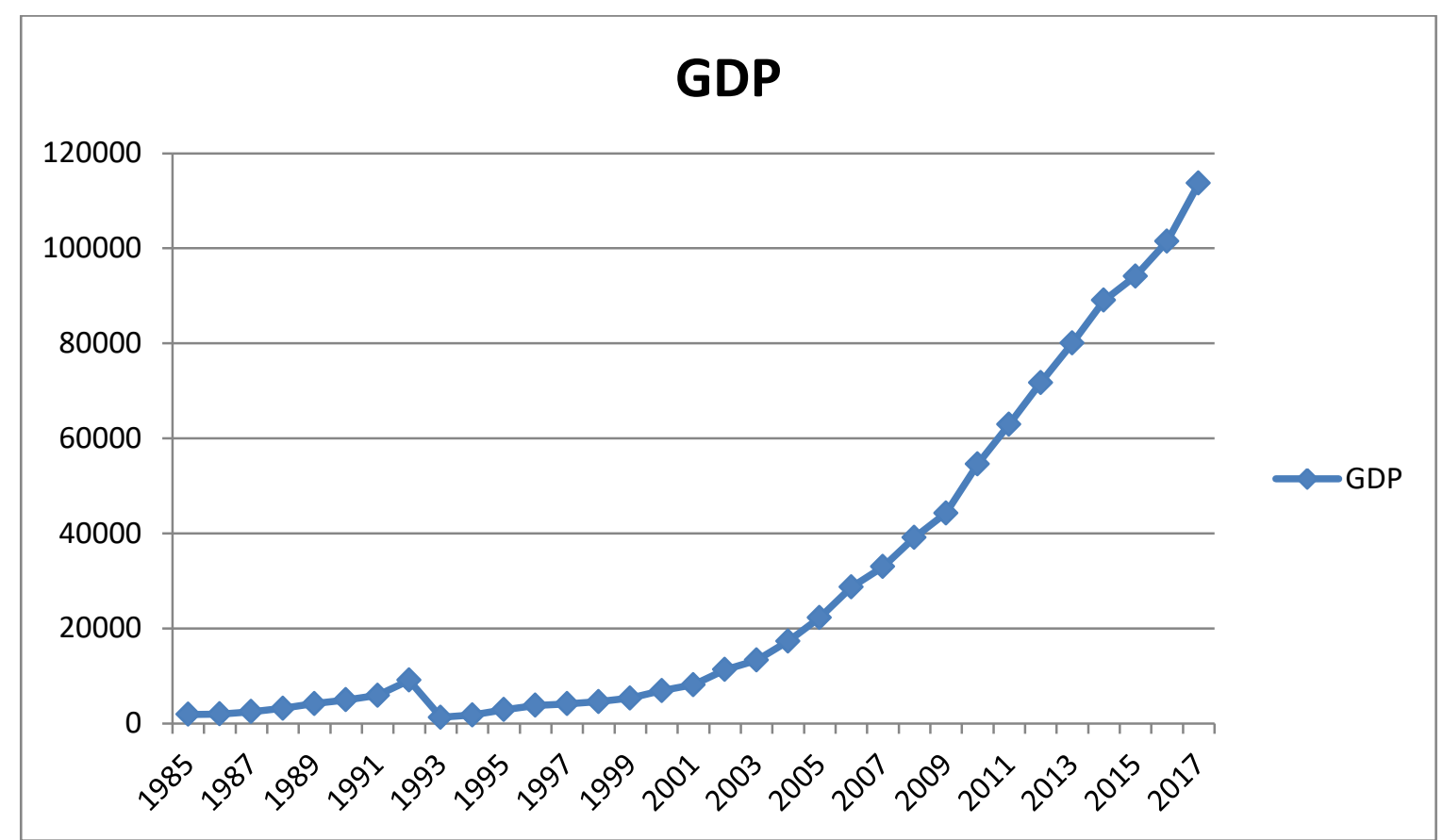

Figure 1b: Trend of Gross Domestic Product (N Billion)

Table 2: Multiple Regression Analysis

Dependent Variable: LOG(GDP)

Method: Least Squares

Date: 05/22/20 Time: 03:23

Sample: 19852017

Included observations: 33

\begin{tabular}{lrlll}
\hline \hline \multicolumn{1}{c}{ Variable } & Coefficient & Std. Error & t-Statistic & Prob. \\
\hline \hline C & 8.353350 & 0.145477 & 57.42053 & 0.0000 \\
REE & 0.009772 & 0.006306 & 1.549602 & 0.1317 \\
SCE & -0.000190 & 0.002672 & -0.071291 & 0.9436 \\
\hline \hline R-squared & 0.819829 & Mean dependent var & 9.412349 \\
Adjusted R-squared & 0.807818 & S.D. dependent var & 1.413352 \\
S.E. of regression & 0.619593 & Akaike info criterion & 1.967001 \\
Sum squared resid & 11.51687 & Schwarz criterion & 2.103047 \\
Log likelihood & -29.45551 & Hannan-Quinn criter. & 2.012776 \\
F-statistic & 68.25441 & Durbin-Watson stat & 0.697737 \\
Prob(F-statistic) & 0.000000 & & & \\
\hline \hline
\end{tabular}

Table 2 presents the regression results of this study analysis. The coefficient of adjusted $\mathrm{R}^{2}$ was about 0.81 , this implies that about $81 \%$ of the included independent variables explain the variation in dependent variable in the model. The coefficient of recurrent expenditure on education was found positive (0.00977) while that of social and community service expenditure was found negative (-0.000190). The F-statistics value of 68.2544 with probability value of $(0.0000)$ implies the model is not statistically significant. Finally, the Durbin Watson statistics of 0.6977 signifies there is presence of positive serial autocorrelation. 
Kemi Olalekan Oduntan: The relationship between education and self-sustainability in a stressed economy

\section{Test of hypotheses}

$\mathbf{H}_{\mathbf{0}}$ 1: There is no significant relationship between recurrent expenditure on education and economic growth in Nigeria.

From the above regression result, the $\mathrm{t}$ statistics of recurrent expenditure on education of 1.5496 is less than 2 , showing an insignificant effect on gross domestic product. The result shows that there is no significant relationship between recurrent expenditure on education and economic growth in Nigeria, which means the hypothesis, is accepted.

$\mathbf{H}_{\mathbf{O}}$ 2: There is no significant relationship between social and community development expenditure and economic growth in Nigeria. The t-statistics of the regression result for social and community development expenditure value of -0.0712 is less than 2 , showing an insignificant effect on economic growth in Nigeria. The result shows that there is no significant relationship between social and community development expenditure and economic growth in Nigeria, which means the hypothesis, is accepted.

\section{Conclusion}

This paper discussed the dilemma in education and its implications for selfsustainability in Nigeria. In this era of global economic competitiveness educational development remains the only alternative to Nigerians for their active participation in the development process. Thus, poverty eradication, ensuring food security and good nutrition, access to water and sanitation, securing sustainable energy, creation of jobs, industrial sector development are without doubt, predicated on good quality and wellcoordinated education.

The researcher used secondary data from the Central Bank of Nigeria Economic Reviews for the years under consideration such as National Gross Domestic Product, Recurrent Expenditure on Education and Recurrent Expenditure on Social and Community Service. The results from the analysis revealed significantly positive and strong relationship between educational policies and educational development in Nigeria and also a very strong and significantly positive relationship between education and self-sustainability in Nigeria. Thus, by further providing adequate funding to education and reduce corruption in the sector to its barest minimum it is expected that many Nigerian will be self-sustaining in the nearest future.

Education is the cornerstone of achieving a sustainable national development. There are no doubts achieving sustainable national development is the goal of all developing nations, Nigeria inclusive. As such there is need to invest, encourage and enlighten people on the value of education. Government should continue the contribution towards achieving this sustainable development. However, there is need for monitoring, supervising and ensuring that all the financial and other investments in education for the purpose of achieving sustainable development are not diverted for other purposes.

Having examined the relationship between education and self-sustainability in Nigeria over the years, the following policy recommendations were drawn from the study inferential results to guide government policy decisions, educational stakeholders and policy makers:

1. A monitoring framework of government expenditure on education targeted at reaching effective and efficient productive activities in all strata of education need to be urgently developed and implemented since it is an important key of achieving sustainable national development.

2. Also educational stakeholders need to review forthwith the role of government and reappraised with more emphasis on providing enabling environment for other stakeholders.

3. Private sector policy makers should be included in the formulation of education policies to ensure the nation attain self-sustainability. 
Kemi Olalekan Oduntan: The relationship between education and self-sustainability in a stressed economy

\section{References}

Ademola-Olateju, B. (2013): "Education in Nigeria: The Missteps, the Gaps http://saharareporters.com/article/educ ation-nigeria-missteps-gaps-part-onebamideleademola-olateju. Accesses, $14 / 11 / 18$.

Age, E. (2005). Objectives of Teaching Education in Nigeria. London, British Council.

Ajimotokan, H., et al (2010): "Engineering Education and Sustainable Development in Nigeria" Journal of Research Information in Civil Engineering 7(1) 93-98.

Akande (2006). "Issues and Challenges in Nigerian Education in the $21^{\text {st }}$ Century". Farfaru Journal, Volume 1.

Akinola, S. (2006): "Structural Transformation and Polycentric Governance: A Constitutional Gateway towards Nigerian Democratization" Paper Presented at a Working Conference on "Designing Constitutional Arrangements for Democratic Governance in Africa: Challenges and Possibilities" Organized by the Workshop in Political Theory and Policy Analysis, African Studies Program, and Office of International Programs, Indiana University, Bloomington, USA, 30-31 March.

Aminu, J. (2006). "Issues and Challenges in Nigerian Education in the 21st Century". Farfaru Journal of MultiDisciplinary Studies Vol. 1. Sokoto.

Anya, A. (2008): "Education, Scholarship and the Wealth and Health of Nation: The Search for the Dialectics of Sustainable development". A Valedictory Lecture; University of Nigeria, Nsukka.

Arogundade, B. (2011): "Entrepreneurship Education: An Imperative for Sustainable Development in Nigeria" Journal of Emerging Trends in Educational Research and Policy Studies (JETERAPS) 2(1): 26-29.
Asodike, J. D. (2005). Empowering Nigerian Rural Women Through Skills Acquisition Programmes. Journal of International Gender Studies (JIGS), University of Port Harcourt (2) 110122.

Asodike, J. D. (2007). Skills Acquisition in Nigerian Secondary Schools: Relevance to Sustainable development. Knowledge Review A Multidisciplinary Journal, National Association for the Advancement of Knowledge, 15 (2) 51-57.

Asodike, J. D. (2008). Analysis of Returns to Investment in Skills Acquisition Programme (SAP) in Rivers State. Unpublished Ph.D Thesis, University of Port Harcourt, Rivers State, Nigeria.

Awoyinfa, S. (2013): "Policy Somersault as FG Dumps 9-3-4 for 1-6-3-3 4" http://www.punching.com. Accessed, 12/11/18.

Ayu, A., Farfaru Journal of MultiDisciplinary Studies 1-2 (1991) 235243.

Baha, I. (2005). Perspective: Education for Sustainable Development. Online News Letter of the Baha I. International Community, 17 (3), 1-3.

Barzel, Y. (2002): A Theory of the State: Economic Rights, Legal Rights, and the Scope of the State. Cambridge: Cambridge University Press.

Basic Education (2011). Available at: http/en. Wikipedia. Org/wiki/Basic Education. Retrieved on 12th May, 2011.

Bolag and Umoh (2002). Nigerian Universities: Start to Recover from years of Violence, Corruption and Neglect. The Chronicle of the Higher Education, Lagos, Nigeria.

Bwala, M. H., Koroma, D. S. (2005). Towards Sustainable Development of Nigeria, Lagos, Nigeria CSS Book shops.

Emeh, J. et al (2011): "Curriculum Review: Reactions from Education Stakeholders in South-South States of 
Kemi Olalekan Oduntan: The relationship between education and self-sustainability in a stressed economy

Nigeria" Global Journal of Human Social Science 11(2) 32-42.

Enamiroro, P. (2007): "Education, Poverty and Development in Nigeria: The Way Forward in the 21st Century" Journal of Social Sciences 14(1) 1924.

Estes, R. (1993): “Toward Sustainable Development: From Theory to Praxis" Social Development Issues 15(3): 129.

Fadekinte, M. (2013): "The Nature and Character of the Nigerian State: Explaining Election Crisis in a Peripheral State" British Journal of Arts and Social Sciences 12(II) 275287.

Fafunwa, A. B. (1974). History of Education in Nigeria. London, George Allen and Unwin.

Fafunwa, A. (1983): Development of Education in Nigeria: Trends and Issues in Nigerian Education. Ife: University of Ife Press Ltd.

Federal Government of Nigeria, (2004). National Policy on Education. 4th Edition Lagos, Nigeria NERCD.

Haralambos, M., Holborn, M. (2004). Sociology Themes and Perspectives, London: Harper Collins Publishers.

Igbuzor O. (2006). State of Education in Nigeria. A key note address delivered at a round table organized by Civil Society Action Coalition on Education for all on 3rd July.

Ikechukwu, O.G., (2006). Farfaru Journal of Multi-Disciplinary Studies (12) 235243.

Ikharehon, J. (2007): "Capacity Building for National Sustainable Development: The Nigerian Experience' Journal of Social Sciences 15 (1) 25-29.

Laski, H. (2008): A Grammar of Politics. Kamla Nagar: Surject Publications Makoju, G. et al (2005): Nigeria Education Sector Diagnosis: A Framework for Re-Engineering the Education Sector. Abuja: Federal Ministry of Education.
Maclean, P. (2008). Education for Peace Building and Sustainable Development: Delusion, Illusion or Reality? Retreived from http://www.daneprairie.com

Mallam-Madori, S. (2013): "Education: Problems and Challenges in Nigeria, What to be done" http://sundaytrust.com.ng/index.php/c omment-debate/12514-educationproblems-and-challenges-in-nigeriawhat-to-be-done. Accessed, 11/11/18.

Marshall, G. (1998): A Dictionary of Sociology. Oxford: Oxford University Press.

Mbagwu, E.O., \& Nwakaire, (2005). Practising Adult and Non-Formal Education within the UBE Law in Nigeria. Adult and Non-Formal Education in Nigeria: Emerging Issues. Ibadan: NNCAE.

McKeown, R. (2002). Education for Sustainable development Toolkit. Retrieved from http://www.esdtoolkit.org

Munasinghe, S. (2004). Effective Instructions Through Dynamic Discipline. Ohio, Charles E. Merill.

Muoghalu, K. (2013a): "The Human Capital Dimension of Economic Transformation" Lecture Delivered at the Golden Jubilee Ceremony of the $1^{\text {st }}$ Graduates of the University of Nigeria, Nsukka.

Muoghalu, K. (2013b): Emerging African: How the Global Economy's 'Last Frontier' Can Prosper and Matter. Ibadan: Bookcraft Ltd.

Nigerian Education (2011). Available at http:www.maps of world. Com/Nigeria Education Retrieved on $12^{\text {th }}$ May.

Nwogu, G. (2013): "Education and National Development in Nigeria: A Philosophical Perspective". African Research Review. 7(2) 266-276.

Nzekwe, F. and Okeke, R. (2014): "Energy Security and Sustainable Development in Nigeria: Prospects and Challenges" Forthcoming. 
Kemi Olalekan Oduntan: The relationship between education and self-sustainability in a stressed economy

Obasan, K. and Akindele-Oscar, T. (2011): "Manpower Planning and Education in Nigeria: Between Hope and Hopelessness" European Journal of Humanities and Social Sciences 8(1) 313-321.

Okeke, R. (2014): "Democracy and Sustainable National Development in Nigeria: Reimagining the Nexus" European Scientific Journal 10(1) 229-248.

Okolie, A. (2012): "Nigerian State and Peasantization of the Civil Society". Nigerian Journal of Social Sciences. 8(1) 33-48.

Okonjo-Iweala, N. et al (2010): 'Nigeria: The Next Generation Report". PGDA Working Paper No. 62. http://www.hsph.harward.edu/pgda/w orking.htmhesive. Downloaded, 12/11/18.

Okorosaye-Orubite, A.K. (2005). Education and Development in School and Society, Eds., Agabi, G.O., Okorosaye-Orubite, A.K., EzekielKart, J., \& Egbezor, D.E. Port Harcourt: Davidstones Pub. Ltd.

Okorosaye-Orubite, A.K. (2007). Education and Sustainable Development in Niger Delta: The Role of Youths, African Journal of Educational Research and Development (AJERD) 1, (1) 72-84.

Okwueze, F. (2011): "Public Administration in the Public-Private Partnership (PPP) as a Strategy for National Development" Nigeria Journal of Social Sciences. 7 (2) 78-94.

Olubademo S.O. (2006). Contemporary Issues in Nigerian Education. Lagos CSS Bookshops.

Onuoha, J. (2008): The State and Economic Reforms in Nigeria: An Exploratory Note on the Capture Theory of Politics, Nsukka: Great AP Express Publishers Ltd.

Orr, D. (n.d) Education of Sustainability Chapter 2 Formal Education Retrieved from http://www.vanguardngr.com/2013/01 /entrepreneurial-education-revolution- animaperative-for-sustainabledevelopment-in-nigeria/ Accessed, $13 / 11 / 18$.

Osuji, F. (2004). Our Youth Our Hope. Paper Presented at the 47th Session of the International Conference on Education Geneva, 8-11 September.

Other Educational developments (2011). Available at http://www.Online Nigeria. Com/Education/ Blunbs 535. Retrieved or 12th May.

Paul, E. et al (2005): Entrepreneurship in Vocational Education. Enugu: Ozybel Publishers.

Peter, R. (1966). The Organizational Climate of Schools. Chicago, University of Chicago Midwest Administration Centre.

Peter O.M. and Juliana D. (2010). Exploring Education as a tool for Sustainable Development in Nigeria, European Scientific Journal May edition vol. 8, No.10 ISSN: 1857 - 7881 (Print) e ISSN 1857- 7431

Rajaj and Chiv, (2009). Education for Sustainable Development As Peace Education. A Paper Presented at Peace History Society and Peace and Justice Studies Association. Ibadan, Nigeria.

Rodney, W. (2009): How Europe Underdeveloped Africa. Abuja: Panaf Publishing.

Rufa'I R. (2000). Speech on 'Lack of Qualified Teachers Responsible For Dismal Performance of Students". Daily Trust $22^{\text {nd }}$ August, 2010.

Salman, M. et al (2011): 'Education Reforms in Nigeria: Implications for the GirlChild Participation in Sciences, Technology and Mathematics (STM)" Education Research Journal 1(1) 1-8.

Tahir G. (2001): Federal Government Intervention in U.B.E. form 1(1) 1-12 Kaduna Nigeria.

Ugoh, S.C. 92008). Oil Politics and Crisis of Development in the Niger Delta. Journal of Sustainable Development in Africa. 10, (2) 91-115. 
Kemi Olalekan Oduntan: The relationship between education and self-sustainability in a stressed economy

UK Panel for Education for Sustainable Development, (1998). Retrieved from http://www.worldaware.org.uk/educat ion/sustain.html

UNESCO (2000). Nigerian Human Resource Development and Civilization: Education and World Affairs, New York.

Victor D. (2002). The State of Education in Nigeria and the health of the Nation.
Zaria, Ahmadu Bello University Press.

Wasagu, M.A., "The Nigerian Educational System and Challenges of Today". Sokoto Farfaru Journal Vol. 1 June, 2006.

World Commission on Environment and Development (1987): Our Common Future. New York: Oxford University Press. 